\title{
Humoral immune response in Japanese acute hepatitis patients with hepatitis $C$ virus infection
}

\author{
N Yamaguchi MD, K Tokushige MD PhD, K Yamauchi MD PhD, N Hayashi MD PhD
}

N Yamaguchi, K Tokushige, K Yamauchi, N Hayashi. Humoral immune response in Japanese acute hepatitis patients with hepatitis C virus infection. Can J Gastroenterol 2000;14(7):593598. The humoral immune response to acute infection by hepatitis $\mathrm{C}$ virus (HCV) is not yet perfectly clear in terms of immunoglobulin (Ig) response, diversity of HCV antigen, and the relation with hepatitis severity and antibody response. Serum IgM and IgG anti-HCV levels in patients with HCV and either acute hepatitis $(\mathrm{AH})$ or fulminant hepatitis $(\mathrm{FH})$ were investigated; the diversity of HCV antigen was investigated by RIBA test III. Of $22 \mathrm{AH}$ patients, $12(54.5 \%)$ were positive for IgM anti-HCV, mainly reacting to $\mathrm{HCV}$ core protein. The mean interval until the appearance of IgM anti-HCV after onset was $24.1 \pm 26.2$ days. IgG anti-HCV mainly reacted to both core and NS-3 antigen, appearing $42.6 \pm 42.1$ days after onset. From a serial study of $15 \mathrm{AH}$ patients, it was considered that in seven $\mathrm{AH}$ patients (46.7\%), the IgM response would precede the IgG response. In another two AH patients, IgM anti-HCV was not detected during the acute disease phase. Of 48 chronic hepatitis patients with HCV-RNA, 40 patients were positive for IgM anti-HCV. Therefore, IgM anti-HCV was useful for diagnosis in some of the AH patients, but it was difficult to use for distinguishing between acute and chronic infection. All four FH patients with HCV-RNA were positive for both IgM and IgG antibody to HCV at onset. Their antibody titres were higher than those of $\mathrm{AH}$ patients. These results suggested that, as in FH due to HBV, FH due to HCV could induce strong and rapid humoral immunity.

Key Words: Acute hepatitis; Fulminant hepatitis; Immunoglobulin M antihepatitis $\mathrm{C}$ virus; RIBA test III

\section{Réaction immunitaire humorale chez des patients japonais atteints d'hépatite $\mathrm{C}$ aiguë}

RÉSUMÉ : La réaction immunitaire à médiation humorale consécutive à une infection aiguë par le virus de l'hépatite C (HCV) n'est pas entièrement élucidée sur les plans de la réponse liée aux immunoglobulines (Ig), de la diversité de l'antigène du HCV et du rapport entre l'intensité de l'hépatite et la réaction immunitaire. Les taux d'IgM et d'IgG anti-HCV sériques chez les patients atteints d'une infection au HCV soit aiguë, soit fulminante (HA ou HF) ont fait l'objet de recherches. La diversité de l'antigène du HCV a été analysée par le test RIBA III. Sur 22 patients atteints de HA, 12 (54,5 \%) se sont révélés séropositifs à l'égard de l'IgM anti-HCV, réagissant principalement à la protéine nucléocapsidique du HCV. L'intervalle moyen jusqu'à l'apparition de l'IgM anti-HCV après la contamination a été de $24,1 \pm 26,2$ jours. L'IgG anti-HCV a principalement réagi aux antigènes nucléocapsidique et NS-3, apparaissant 42,6 $\pm 42,1$ jours après le déclenchement. À partir d'une étude sériée de 15 patients souffrant d'HA, on a jugé que chez sept de ces patients $(46,7 \%)$, la réponse de l'IgM précéderait la réponse de l'IgG. Chez deux autres patients atteints d'HA, l'IgM anti-HCV n'a pas été décelée durant la phase aiguë de la maladie. Parmi les 48 patients atteints d'hépatite chronique avec ARN du HCV, 40 patients étaient séropositifs à l'égard de l'IgM anti-HCV. Par conséquent, l'IgM anti-HCV s'est révélé utile pour le diagnostic de certains patients atteints d'HA, mais il a été difficile de l'utiliser pour distinguer l'infection aiguë de l'infection chronique. Les quatre patients atteints d'HF avec ARN du HCV étaient positifs à l'égard de l'IgM et de l'IgG dirigés contre le HCV au départ. Leurs titres d'anticorps étaient plus élevés que ceux des patients atteints d'HA. Ces résultats donnent à penser que, comme dans l'HF due au l'HBV, l'HF due au HCV pourrait induire une immunité humorale forte et rapide.

Division of Medicine, Institute of Gastroenterology, Tokyo Women's Medical College, Tokyo, Japan

Correspondence and reprints: Dr Katsutoshi Tokushige, Division of Medicine, Institute of Gastroenterology, Tokyo Women's Medical College, 8-1 Kawada-cho, Shinjuku-ku, Tokyo, 162, Japan. Telephone +81-3-3353-8111,fax +81-3-5269-7430, e-mail rkg-yama@po.jah.ne.jp Received for publication April 19, 1999. Accepted January 10, 2000 
$\mathrm{D}_{\mathrm{r}}^{\mathrm{c}}$ etection of immunoglobulin (Ig) M antibody usually precedes that of IgG antibody in viral infection, such as infection by hepatitis A virus (HAV) or hepatitis B virus (HBV). Several studies have indicated that the measurement of serum IgM antihepatitis $\mathrm{C}$ virus (HCV) might be useful for the diagnosis of acute infection of HCV (1-3). However, Kikuchi et al (4) reported that IgM response was not observed or was weak in acute HCV infection. We investigated the IgM response with the use of a third generation assay system of anti-HCV, which has good sensitivity, and reassessed the clinical significance of IgM anti-HCV in acute hepatitis $(\mathrm{AH})$.

The single-stranded RNA genome of $\mathrm{HCV}$ encodes at least three structural proteins - core, envelope (E) 1 and E2 and at least six nonstructural (NS) proteins - NS-2, NS-3, NS-4a, NS-4b, NS-5a and NS-5b (5-7). Antibodies against these viral proteins are readily detected with the use of ligands such as synthetic peptides or recombinant proteins (8-13). However, it is still not clear which HCV protein initially induces the antibody response in $\mathrm{AH}$ patients. In this study, we examined the response to individual $\mathrm{HCV}$ proteins by RIBA test III.

$\mathrm{HCV}$ is reported to be one of the causative agents of fulminant hepatitis (FH) $(14,15)$. In FH patients with HBV, antihepatitis B surface (HBs) antibody appeared rapidly (1618). In FH patients with HBV who were diagnosed by IgM antihepatitis B core ( $\mathrm{HBc}$ ) and HBV-DNA, HBs antigen was sometimes not detected. Therefore, an IgM antibody anti-HBc was considered the most useful serological marker for the diagnosis of FH patients with HBV. Four FH patients were infected with HCV-RNA. We attempted to examine the humoral immune response to $\mathrm{HCV}$ in $\mathrm{FH}$ patients infected with HCV, and discuss the relationship between the severity of hepatitis and antibody response.

\section{PATIENTS AND METHODS}

Patients: Twenty-two AH patients and four $\mathrm{FH}$ patients with HCV-RNA were studied. All AH and FH patients were diagnosed both by histological findings and by various serological examinations, including serum HCV-RNA by reverse transcriptase polymerase chain reaction (RT-PCR) (19). These AH patients had no serological markers of HAV, HBV, cytomegalovirus or Epstein-Barr virus, nor did they present with any other obvious causes of hepatitis (alcohol abuse, drug hypersensitivity or autoimmune disease). The pathological findings of all $\mathrm{AH}$ patients showed typical features of acute liver injury without chronic changes such as portal fibrosis. As for the infectious source, three had histories of blood transfusion, three had needle accidents, three had operations and two had sexual contact with partners with HCV; 11 had no history of exposure. The AH patients ranged in age from 18 to 78 years and consisted of 10 men and 12 women. All FH patients were diagnosed by the criteria of Takahashi and Shimizu (20). In brief, the patients with normal liver function before the onset of illness, hepatic coma over grade $\mathrm{H}$ and elongated prothrombin time (less than $40 \%$ of control) were diagnosed as positive.
None of the four FH patients with HCV-RNA had histories of drug exposure or alcohol consumption, and all four were negative for autoantibody. One patient had both HCV and hepatitis $\mathrm{G}$ virus (HGV) as detected by RT-PCR (21), and the other three FH patients had no viral markers (IgM anti-HAV, HBs antigen, HBs antibody, hepatitis 'e' antigen, hepatitis 'e' antibody, $\mathrm{HBc}$ antibody, IgM-HBc antibody and HBV-DNA by PCR (22), and HGV-RNA by RT-PCR). Their histological changes consisted of massive or submassive necrosis. One survived and three died.

The controls were 11 healthy subjects (with normal liver function and without the above-mentioned viral markers), $10 \mathrm{AH}$ patients (five $\mathrm{HBV}$ and five $\mathrm{HAV}$ ), seven $\mathrm{FH}$ patients (negative for HAV, HBV, HCV and HGV markers), 10 chronic hepatitis patients with HBV and 48 chronic hepatitis patients with HCV. All chronic hepatitis patients were diagnosed by histological findings and viral markers (positive for both HCV-RNA and anti-HCV or positive for HBs antigen).

Antibody assay: IgM and $\operatorname{IgG}$ anti-HCV were measured by third generation HCV antibody assay kit (HCV EIA 3.0, Abbott Laboratories, USA), in which a peroxidase-conjugated goat affinity-purified antibody to human IgM or IgG (Cappel, USA) was used as a second antibody. This assay enabled the detection of antibodies to HC-34, HC-43, c100-3 and NS-5. Serum samples were diluted 1:40 (IgM and $\operatorname{IgG}$ ) in $200 \mu \mathrm{L}$ of specimen diluent. In these dilutions, beads with previous $\mathrm{HCV}$ antigen adhering to their surface were incubated for $2 \mathrm{~h}$ at $40^{\circ} \mathrm{C}$ while being shaken. After three washings, the beads were loaded with $200 \mu \mathrm{L}$ of peroxidaseconjugated goat affinity-purified antibody to human IgM or IgG and incubated for $30 \mathrm{~min}$ at $40^{\circ} \mathrm{C}$ while being shaken. The beads were washed three times and incubated for $30 \mathrm{~min}$ at room temperature with $300 \mu \mathrm{L}$ of peroxidase substrate ( $3 \mathrm{mg} / \mathrm{mL} \mathrm{O-phenylenedamine,} 0.02 \%$ [volume/volume] hydrogen peroxide). The reaction was stopped with $300 \mu \mathrm{L}$ of $2 \mathrm{~mol} / \mathrm{L}$ sulphuric acid, and the colour was read with a reader at a wavelength of $492 \mathrm{~nm}$ with a reference beam at $570 \mathrm{~nm}$. The maximum optical density titre of $\operatorname{IgG}$ was 2.0 and that of IgM was 3.0. Three control sera from healthy individuals with normal liver function were included in each assay. All samples were assayed in duplicate.

RIBA test III: The sera of AH patients were analyzed for IgM and IgG anti-HCV to individual HCV proteins by HCV RIBA test III (Ortho Diagnostics Systems, USA). The assay kit contained the following recombinant antigens: c22p (core), c33c (NS-3), c100p (NS-4), NS-5, superoxide dismutase and anti-IgG antibody. Analysis was carried out according to the instructions of the manufacturer and Buffet et al (23). In brief, $20 \mu \mathrm{L}$ (IgG) and $40 \mu \mathrm{L}$ (IgM) of sera with $1 \mathrm{~mL}$ of dilution buffer were incubated with a strip adhering these HCV antigens and shaken for $4 \mathrm{~h}$. After three washes with phosphate-buffered saline, a second antibody of the same antibody described in the antibody assay was added and incubated for $10 \mathrm{~min}$. After three washes, the substrate solution was added and the density of the band was determined. 
TABLE 1

Clinical and laboratory data of acute hepatitis patients with hepatitis $\mathrm{C}$ virus (HCV) infection

\begin{tabular}{|c|c|c|c|c|c|}
\hline Patient & Age (years)/sex & Source of infection & AST peak (IU/L) & Interferon treatment & HCV-RNA of endpoint \\
\hline$A-1$ & $21 / F$ & Unknown & 714 & - & Sustained \\
\hline$A-2$ & $26 / F$ & Needle accident & 1010 & + & Cleared \\
\hline A-4 & $61 / M$ & Operation & 1449 & + & Sustained \\
\hline$A-5$ & $29 / M$ & Unknown & 1354 & + & Cleared \\
\hline B-1 & $78 / F$ & Unknown & 1173 & - & Cleared \\
\hline B-2 & $51 / \mathrm{M}$ & Unknown & 2185 & - & Sustained \\
\hline B-3 & $32 / \mathrm{M}$ & Unknown & 644 & + & Cleared \\
\hline B-4 & $47 / M$ & Unknown & 2952 & - & Sustained \\
\hline $\mathrm{D}-2$ & $26 / \mathrm{F}$ & Sexual contact & 1050 & + & Cleared \\
\hline $\mathrm{E}-1$ & $18 / \mathrm{F}$ & Unknown & 1072 & - & Cleared \\
\hline $\mathrm{E}-2$ & $36 / F$ & Transfusion & 1538 & - & Sustained \\
\hline $\mathrm{E}-3$ & $28 / F$ & Sexual contact & 1902 & + & Cleared \\
\hline E-4 & $78 / \mathrm{M}$ & Transfusion & 415 & - & Sustained \\
\hline E-5 & $20 / M$ & Unknown & 2731 & + & Sustained \\
\hline$E-6$ & $56 / F$ & Operation & 351 & - & Sustained \\
\hline$E-7$ & $26 / F$ & Unknown & 204 & + & Sustained \\
\hline
\end{tabular}

AST Aspartate aminotransferase; F Female; M Male

Statistical analysis: Statistical analysis was performed by unpaired $t$ test. $\mathrm{P}<0.05$ was considered significant.

\section{RESULTS}

Prevalence of IgM to HCV in acute liver diseases: Twentytwo AH patients and four FH patients with HCV-RNA were analyzed (Tables 1,2). Twelve of the $22 \mathrm{AH}$ patients received interferon therapy. Ten AH patients were cleared of HCVRNA - eight by IFN therapy and two by the natural course. The others became chronically infected.

The IgM response in the various liver diseases was investigated (Figure 1). The cutoff titer of IgM anti-HCV (0.531) was determined by adding three standard deviations to the mean titre of non-HCV hepatitis patients and healthy controls. IgM antibody to HCV was detected in $12(54.5 \%)$ of the $22 \mathrm{AH}$ patients with $\mathrm{HCV}$, all four $(100 \%) \mathrm{FH}$ patients with $\mathrm{HCV}$ and $40(83.3 \%)$ of $48 \mathrm{CH}$ patients with $\mathrm{HCV}$ (Figure 1); however, there was no correlation among IgM response and resolution, serum alanine aminotransferase and serum bilirubin of AH. In comparison, this antibody was not detected in 11 healthy subjects, all $10 \mathrm{AH}$ patients with $\mathrm{HAV}$ or $\mathrm{HBV}$, seven $\mathrm{FH}$ patients (non-A, non-B, non-C) and $10 \mathrm{CH}$ patients with HBV.

Titre (mean $\pm \mathrm{SD}$ ) of IgM anti-HCV was highest in $\mathrm{FH}$ patients with $\mathrm{HCV}(2.072 \pm 1.094)$, followed by $\mathrm{CH}$ patients with HCV $(1.816 \pm 1.108)$ and then AH patients with HCV
TABLE 2

Immunoglobulin (Ig) $M$ and IgG antibodies in fulminant hepatitis patients with hepatitis $\mathrm{C}$ virus (HCV)-RNA

\begin{tabular}{lccccc}
\hline Patient & Age/sex & HCV & $\begin{array}{c}\text { IgM anti- IgG anti- } \\
\text { HCV }\end{array}$ & $\begin{array}{c}\text { HCV-RNA } \\
\text { (PCR) }\end{array}$ & $\begin{array}{c}\text { HCV-RNA } \\
\text { (probe) }\end{array}$ \\
\hline 1 & $40 / \mathrm{F}$ & $>3.0$ & $>2.0$ & + & $<0.24 \mathrm{Meq} / \mathrm{mL}$ \\
2 & $31 / \mathrm{M}$ & $>3.0$ & $>2.0$ & $+(\mathrm{HGV}+)$ & Not done \\
3 & $56 / \mathrm{F}$ & 0.871 & $>2.0$ & + & $<0.24 \mathrm{Meq} / \mathrm{mL}$ \\
4 & $47 / \mathrm{M}$ & 1.419 & $>2.0$ & + & Not done \\
\hline
\end{tabular}

HGV Hepatitis G virus; PCR Polymerase chain reaction

$(0.943 \pm 0.885)$. Table 2 shows the data of IgM and IgG anti$\mathrm{HCV}$ in FH patients with HCV-RNA. In all FH patients, both antibodies were already detected at onset. These results suggest that fulminant hepatic failure with $\mathrm{HCV}$ might induce rapid and strong humoral immunity, as occurs in $\mathrm{FH}$ induced by HBV. In contrast to $\mathrm{CH}$ patients with $\mathrm{HBV}$, IgM anti-HCV was detected in the majority of $\mathrm{CH}$ patients with $\mathrm{HCV}$.

Serial study of AH patients: Serial samples from $15 \mathrm{AH}$ patients with HCV-RNA were assayed to establish the pattern of appearance of IgM and IgG anti-HCV (Figure 2). In the initial samples, 10 (66.7\%) were positive for IgM anti-HCV and nine $(60 \%)$ for IgG anti-HCV. IgG anti-HCV eventually became positive in all $\mathrm{AH}$ patients. IgM appeared be- 


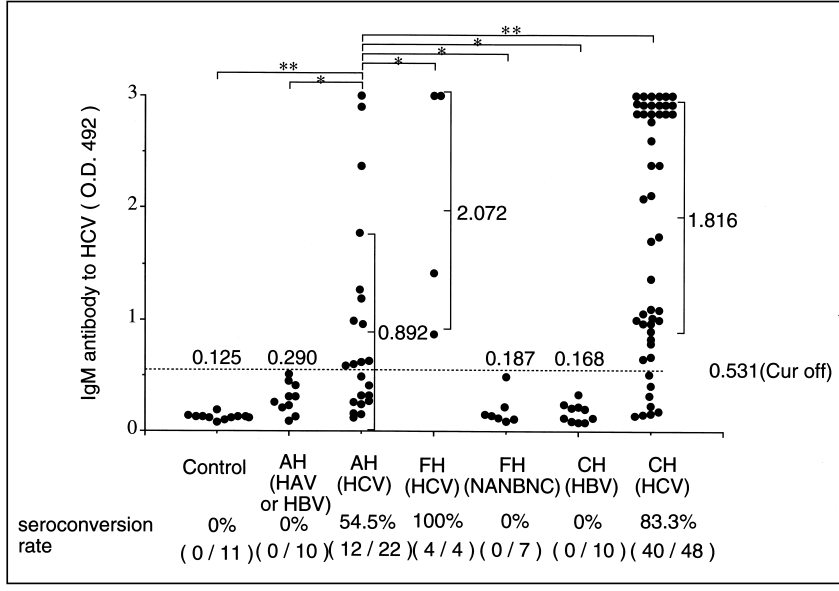

Figure 1) The titre of immunoglobulin ( $\mathrm{Ig}$ ) $\mathrm{M}$ antihepatitis $\mathrm{C}$ virus (HCV) in various diseases. The cutoff titre of IgM anti-HCV (0.531) was determined by adding three standard deviations to the mean titres of non-C hepatitis patients and healthy controls. IgM antibody to HCV was detected in $12(54.5 \%)$ of the 22 acute hepatitis (AH) patients with $\mathrm{HCV}$, all four (100\%) fulminant hepatitis (FH) patients with HCV and $40(83.3 \%)$ of 48 chronic hepatitis $(\mathrm{CH})$ patients with HCV. Mean IgM antibody titres of each group are shown. In comparisons of patients with $\mathrm{AH}$ due to $\mathrm{HCV}, * P<0.05 ; * * P<0.01$. HAV Hepatitis A virus; HBV Hepatitis B virus; NANBNC Non-A, non-B, non-C; OD Optical density

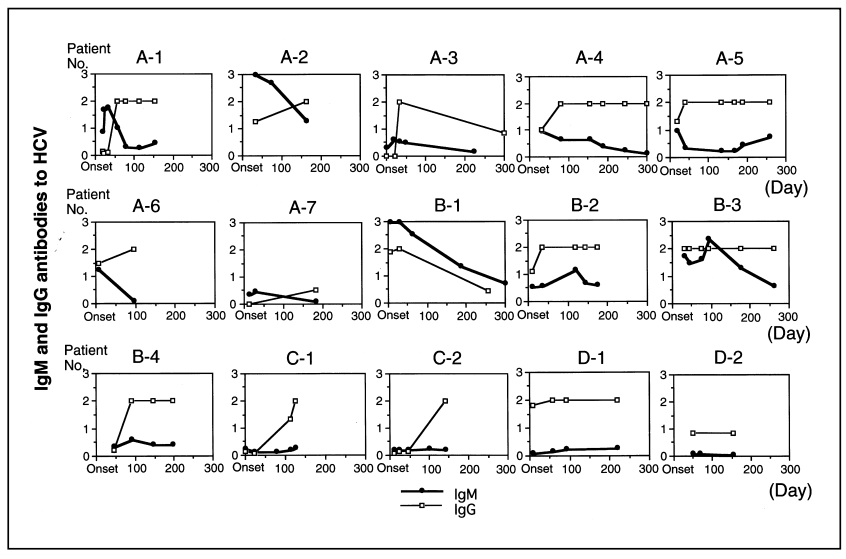

Figure 2) Serial study of immunoglobulin (Ig) G and IgM antihepatitis $\mathrm{C}$ virus $(\mathrm{HCV})$ in 15 patients with acute hepatitis

tween zero and 91 days after the onset of symptoms (mean \pm SD 24.1 \pm 26.2 days), and $\mathrm{IgG}$ anti-HCV appeared between four and 140 days $(42.5 \pm 42.1$ days $)$ after the onset of symptoms. In patients A-1, A-2, A-3 and A-7, IgM antibody response preceded that of $\mathrm{IgG}$, and an Ig class switch from IgM to IgG against $\mathrm{HCV}$ was observed. A class switch was not detected in patients A-4, A-5 and A-6, but from the pattern of two antibodies, it was presumed that the IgM response would have preceded the IgG response to HCV. Of $15 \mathrm{AH}$ patients, seven $\mathrm{AH}$ patients $(46.7 \%)$ were considered to have undergone an Ig class switch. In patients B-1, B-2, B-3 and B-4, IgM became positive later or simultaneously with the $\mathrm{IgG}$ response. IgM anti-HCV was not detected in patients $\mathrm{C}-1$ and $\mathrm{C}-2$ during the acute disease phase, which occurred even before IgG anti-HCV was detected. In patients

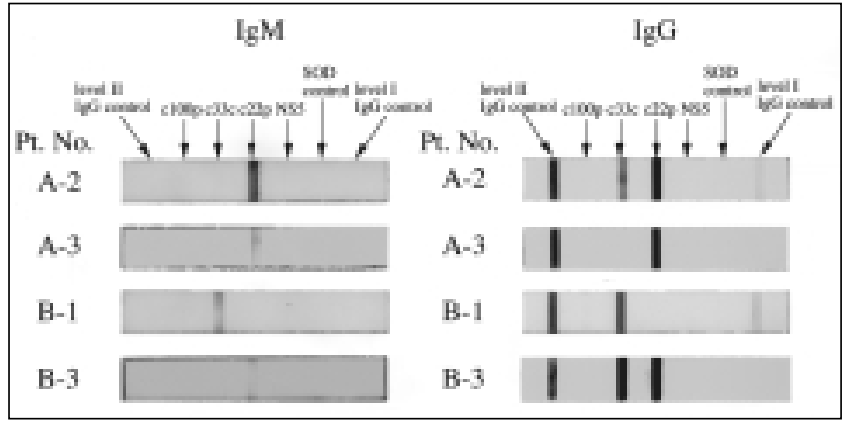

Figure 3) Immunoglobulin (Ig) $\mathrm{M}$ and $\operatorname{IgG}$ responses to individual hepatitis $\mathrm{C}$ virus (HCV) antigens by HCV RIBA test III in representative acute hepatitis cases. A common IgG band in the IgM assay was not detected, suggesting that the second antibody in the assay system showed no crossreactivity with IgG. Pt. No. Patient number; SOD Superoxide dismutase

TABLE 3

Reactivity for individual hepatitis C virus (HCV) protein of immunoglobulin (Ig) $M$ and $\operatorname{lgG}$ antibodies in patients with acute hepatitis patients with HCV

\begin{tabular}{cccccc}
\hline $\begin{array}{c}\text { C22p } \\
\text { (core) }\end{array}$ & $\begin{array}{c}\text { C33c } \\
\text { (NS-3) }\end{array}$ & core+NS-3 & $\begin{array}{c}\text { C100p } \\
\text { (NS-4) }\end{array}$ & NS-5 \\
\hline $\operatorname{lgM}$ & $9 / 11$ & $1 / 11$ & $0 / 11$ & $1 / 11$ & $0 / 11$ \\
& $(81.8 \%)$ & $(9.1 \%)$ & $(0 \%)$ & $(9.1 \%)$ & $(0 \%)$ \\
$\lg \mathrm{C}$ & $4 / 18$ & $6 / 18$ & $8 / 18$ & $0 / 18$ & $0 / 18$ \\
& $(22.2 \%)$ & $(33.3 \%)$ & $(44.4 \%)$ & $(0 \%)$ & $(0 \%)$ \\
\hline
\end{tabular}

NS Nonstructural protein

D-1 and D-2, the IgG response had already reached a maximum level when the first samples were measured. Thus, in these group $\mathrm{D}$ cases, it might have been too late to measure the IgM response of $\mathrm{AH}$, although the clinical, serological and pathological findings of these two patients were indicative of $\mathrm{AH}$.

Antigen diversity of antibody in $\mathrm{AH}$ patients: $\mathrm{AH}$ patients were analyzed for reactivity of IgM and IgG antibodies to individual HCV protein by RIBA test III. Figure 3 shows representative cases. A common IgG band for the controls was not found on examination of IgM antibody, suggesting that the second antibody to human IgM had no crossreactivity with IgG antibody. In nine of $11 \mathrm{AH}$ patients, IgM antibodies mainly reacted to $\mathrm{c} 22 \mathrm{p}$ (HCV core) antigen. In the other two, one was to 33 e (NS-3) antigen and the other to c100p (NS-4) antigen (Table 3). Regarding IgG anti-HCV, in eight of $18 \mathrm{AH}$ patients, IgG antibodies reacted to both core and NS-3 antigen, six to NS-3 and four to core antigen.

\section{DISCUSSION}

We reassessed the clinical features of IgM anti-HCV in AH patients with HCV-RNA. In this study, a third generation HCV antibody assay system (Abbott) was used. Previous studies used measurements by IgM anti-HCV core or C100-3 protein (14). IgM antibody in our system was recognized with core, NS-3, NS-4 and NS-5 proteins. The sensitivity of our system was considered to be higher that that found in other 
studies. As shown in Table 2, IgM antibodies of two AH patients recognized NS-3 or NS-4.

The question of the possibility of false positive must still be answered. If the patients have rheumatoid factor and IgM antibody reacts to an $\mathrm{IgG}$, an $\operatorname{IgG}$ control band must be observed in the IgM RIBA III test. An IgG control band was never detected throughout the IgM RIBA III test. In addition, we measured IgM anti-HCV in 11 healthy controls and 27 non-HCV hepatitis patients, which were all negative. Therefore, we believe that there was no false positive. As for the possibility of false negative, in $\mathrm{AH}$ patients with $\mathrm{HCV}$, the amount of IgG anti-HCV was small compared with that of $\mathrm{CH}$ patients with $\mathrm{HCV}$. Especially in $\mathrm{AH}$ cases in whom the IgM response preceded the IgG response, IgG anti-HCV antibody did not compete with IgM anti-HCV antibody even though $\operatorname{IgG}$ was not removed from serum.

In our $\mathrm{AH}$ patients with $\mathrm{HCV}$-RNA, IgM anti-HCV was detected in $55 \%$. Sato et al (3) reported almost the same results, with 11 of $27 \mathrm{AH}$ patients (40.7\%) being $\mathrm{AH}$-positive for IgM anti-HCV. In our study, $46.7 \%$ of $\mathrm{AH}$ patients indicated that the IgM response would precede the IgG response, similar to observation of acute infection by HAV or HBV. However, in two AH cases, as shown in Figure 2, we did not detect IgM anti-HCV during the acute disease period. Two possibilities for this negative IgM response were considered. One was related to the quantity of HCV-RNA. Many studies have indicated that low levels of circulating HCV-RNA, and thus viral particles $\left(10^{4}\right.$ to $\left.10^{8} / \mathrm{mL}\right)$, are present in serum during HCV infection $(24,25)$ compared with HBV-DNA. Therefore, HCV might not induce the initial humoral immunity effectively. The other possibility concerned the time of the appearance of IgM anti-HCV because it might have appeared much earlier.

IgM and IgG anti-HCV were more frequently detected and the titre was higher in $\mathrm{FH}$ patients with $\mathrm{HCV}$ than in patients with ordinary AH. Akbar et al (26) reported that, of eight patients with FH and subacute hepatitis, three (37.5\%) were positive for IgM anti-C100-3, a difference possibly related to the use of a different antigen in the assay system. In patients with FH due to HBV, anti-HBs antibody also appeared earlier than in patients with ordinary $\mathrm{AH}$ due to HBV (16-18). We speculated that severe liver damage can induce strong and rapid humoral immunity through several cytokines. We reported that the serum level of interleukin-6, which could change B cells to antibody-producing cells, was markedly high in FH patients (27). The present results support our hypothesis. The possibility was also raised that HCV infects patients chronically and that some other virus or factor induces acute hepatic failure. However, the major hepatic pathological finding in all four $\mathrm{FH}$ patients was massive necrosis without chronic change, such as portal fibrosis. One patient was infected with HCV and HGV. The other three FH patients were negative for other virus markers except $\mathrm{HCV}$, were negative for autoantibody, and had no history of drug or alcohol abuse. From the clinical and serological data and histological findings, we believe that acute hepatic failure was induced by HCV in these four patients. In fact, HCV has already been reported to induce fulminant hepatic failure $(14,15)$.

As for the diversity of $\mathrm{HCV}$ antigens, our study indicated that IgM antibodies were induced by HCV core antigen and IgG antibodies by HCV core and NS-3 antigens. Our examination of $\mathrm{HCV}$ antigen diversity for IgM antibody appears to be the first reported. Regarding the IgG response, Chen et al (28) reported that the $\mathrm{HCV}$ core antigen was more immunogenic than other viral antigens in $\mathrm{AH}$ patients. They stated that the reason for the difference in immune response to HCV core antigen compared with other viral antigens was not clear, but the core protein was considered to be expressed at higher levels than other proteins. Animal studies of the immunogenicity of HCV core (29), NS-3 (30) and NS-4a (31) antigens have shown that recombinant versions of these HCV proteins delivered as adjuvants elicit respectable levels of antibody. However, the immune responses were different between natural infection and induction with recombinant proteins. In any case, $\mathrm{HCV}$ core antigen could be expected to at first induce humoral immune response, as does HBV core antigen.

IgM antibody is usually detected in the acute phase of viral infection and then disappears. However, IgM antibody to $\mathrm{HCV}$ is detected more frequently in chronic hepatitis. Yuki et al (32) and Brillanti et al (33) reported that IgM antibody to $\mathrm{HCV}$ was correlated with viral replication and hepatitis activity and was a good marker of antiviral therapy. We found the IgM antibody to HCV to be a good parameter for IFN therapy, especially genotype $1 \mathrm{~b}$ (data not shown). The mechanism of the appearance of IgM antibody in chronic $\mathrm{HCV}$ infection was unclear. As one possibility, a relation between B cell lymphoma and HCV chronic infection has been reported $(34,35)$. In this regard, chronic infection with $\mathrm{HCV}$ might stimulate B cell lymphocytes and secrete IgM antibody. In any event, it was difficult to distinguish between acute infection and chronic infection solely by the IgM antibody to $\mathrm{HCV}$.

\section{REFERENCES}

1. Quiroga JA, Cahpillo ML, Catillo I, Bartolome J, Porres JC, Carreno V. IgM antibody to hepatitis $\mathrm{C}$ virus in acute and chronic hepatitis C. Hepatology 1991;14:38-43.

2. Chen PJ, Wang JT, Hwang LH, et al. Transient immunoglobulin M antibody response to hepatitis $\mathrm{C}$ virus capsid antigen in posttransfusion hepatitis C: Putative serological marker for acute and viral infection. Proc Natl Acad Sci USA 1992;89:5971-5.

3. Sato S, Fujiyama S, Tanaka M, et al. IgM and IgA antibodies generated against hepatitis $C$ virus core antigen in patients with acute and chronic HCV infection. Dig Dis Sci 1994;39:2022-31.

4. Kikuchi T, Onji M, Michitaka K, Sito I, Miyamura T, Ohta Y. Anti-HCV immunoglobulin M antibody in patients with hepatitis C. J Gastroenterol Hepatol 1992;7:246-8.

5. Chambers TJ, Haln C, Galler R, Rice CM. Flavivirus genome organization, expression, and replication. Annu Rev Microbiol 1990;44:649-88.

6. Choo QL, Richman KH, Han JH, et al. Genetic organization and diversity of hepatitis $\mathrm{C}$ virus. Proc Natl Acad Sci USA 1991;88:2451-5.

7. Selby MJ, Choo QL, Berger K, et al. Expression, identification and subcellular localization of the proteins encoded by hepatitis $C$ viral genome. J Gen Virol 1993;74:1103-13.

8. Nakatsuji Y, Matsumoto A, Tanaka E, Ogata E, Kiyosawa K. 
Detection of chronic hepatitis $C$ virus infection by 4 diagnostic systems -1 st generation and 2 nd generation enzyme-linked immunosorbent assay, 2 nd generation recombinant immunoblot assay and nested polymerase chain reaction analysis. Hepatology 1992;16:300-5.

9. Chien DY, Choo QL, Tabrizi A, et al. Diagnosis hepatitis C virus (HCV) infection using an immunodominant chimeric polyprotein to capture circulating antibodies: reevaluation of the role of $\mathrm{HCV}$ in liver disease. Proc Natl Acad Sci USA 1992;89:10011-5.

10. Ching WM, Wychowski C, Beach MJ, et al. Interaction of immune sera with synthetic peptides corresponding to the structural protein region of hepatitis C virus. Proc Natl Acad USA 1992,89:3190-4.

11. Ching WM, Wychowski C, Beach MJ, et al. Isolation of a cDNA clone derived from a blood borne non-A, non-B viral hepatitis genome. Science 1989;244:359-62.

12. Kuo G, Choo QL, Alter MJ, Stevens CE. An assay for circulating antibodies to a major etiologic virus of human non-A, non-B hepatitis. Science 1989;244:362-4.

13. Sallberg M, Ruden U, Wahren B, Manius LO. Immunodominant regions within the hepatitis $C$ virus core and putative matrix proteins. J Clin Microbiol 1992;30:1989-94.

14. Farci P, Alter HJ, Shimada A, et al. Hepatitis C virus-associated fulminant hepatic failure. Lancet 1996;335:631-4.

15. Yoshiba M, Dehara K, Inoue K, Okamoto H, Mayumi M. Contribution of hepatitis $\mathrm{C}$ virus to non-A, non-B fulminant hepatitis in Japan. Hepatology 1994;19:829-35.

16. Trepo CG, Robert D, Montin J, et al. Hepatitis B antigen (HBsAg) and/or antibodies (anti-HBs and anti-HBc) in fulminant hepatitis: pathological and prognostic significance. Gut 1976;17:10-3.

17. Woolf IL, El Sheikh N, Cullens H, et al. Enhanced Hbs Ab production in pathogenesis of fulminant viral hepatitis type $\mathrm{B}$. Br Med J 1976;2:669-71.

18. Gimson AES, Tedder RS, Eddleston AL, Williams R. Serological markers in fulminant hepatitis B. Gut 1983;24:615-7.

19. Okamoto H, Okada S, Sugiyama H, et al. Detection of hepatitis C virus by two-stage polymerase chain reaction with two pairs of primers deduced from the 5 noncoding region. Jpn J Exp Med 1990;60:215-22.

20. Takahashi Y, Shimizu M. The study group of fulminant hepatitis. Aetiology and prognosis of fulminant viral hepatitis in Japan: A multicentre study. J Gastroenterol Hepatol 1991;6:159-64.

21. Ishikawa $K$, Hasegawa $K$, Kojima $T$, et al. $\mathrm{HGV}$ is a rare but possible causative agent of non-A-C fulminant hepatitis. Hepatology 1996;24(Suppl):527A. (Abst)
22. Kato J, Hasegawa K, Torii N, Yamauchi K, Hayashi N. A molecular analysis of viral persistence in surface antigen-negative chronic hepatitis. Hepatology 1996;23:389-95.

23. Buffet C, Chamaux N, Laurent-Puig P, et al. Enhanced detection of antibodies to hepatitis $\mathrm{C}$ virus by use of a third generation recombinant immunoblot assay. J Med Virol 1994;43:259-61.

24. Yun Z, Lundeberg A, Johansson B, et al. Colorimetric detection of competitive PCR products for quantitation of hepatitis $\mathrm{C}$ viremia. J Virol Methods 1994;47:1-13.

25. Chen M, Sonnerborg A, Sallberg M. Levels of hepatitis C virus (HCV) RNA in serum and their relationship to levels of immunoglobulin $\mathrm{M}$ and $\mathrm{G}$ antibodies against $\mathrm{HCV}$ core protein. J Clin Microbiol 1995;33:778-80.

26. Akbar SM, Onji M, Horiike N, Ohta Y. Anti-HCV immunoglobulin M antibody in patients with acute and fulminant hepatitis C. Gastroenterol Japn 1993;28(Suppl 5):71-5.

27. Sun Y, Tokushige K, Isono E, Yamauchi K, Obata H. Elevated serum interleukin-6 levels in patients with acute hepatitis. J Clin Immunol 1992;12:197-200.

28. Chen M, Sallberg M, Sonnerborg A, et al. Limited humoral immunity in hepatitis C virus infection. Gastroenterology 1996;116:135-43.

29. Chen Z, Berkower I, Wang RY-H, Ching W-M, Alter HJ, Shih JW-K. Genetic control of the murine humoral response to distinct epitopes of hepatitis C virus core protein. J Viral Hepatitis 1995;2:9-17.

30. Sallberg M, Zhang Z-X, Chen M, et al. Immunogenicity and antigenicity of ATPase/helicase domain of the hepatitis $\mathrm{C}$ virus nonstructural 3 protein. J Gen Virol 1996;77:2721-8.

31. Zhang Z-X, Chen M, Birkett A, Milich DR, Sallberg M. Immune responses to the hepatitis $\mathrm{C}$ virus NS4a are profoundly influenced by the combination of the viral genotype and the host major histocompatibility complex. J Gen Virol 1997;78:2735-46.

32. Yuki N, Hayashi N, Ohkawa K, et al. The significance of immunoglobulin $\mathrm{M}$ antibody response to hepatitis $\mathrm{C}$ virus core protein in patients with chronic hepatitis C. Hepatology 1995;22:402-6.

33. Brillanti S, Masci C, Ricci P, Miglioli M, Barbara L. Significance of IgM antibody to hepatitis $\mathrm{C}$ virus in patients with chronic hepatitis $\mathrm{C}$. Hepatology 1992;15:998-1001.

34. Ferri C, Caracciolo F, Zignego AL, et al. Hepatitis C virus infection in patients with non-Hodgkin's lymphoma. Br J Hematol 1994;88:392-4.

35. Zuckerman E, Zuckerman T, Levine AM, et al. Hepatitis C virus infection in patients with B-cell non-Hodgkin's lymphoma. Ann Intern Med 1997;127:423-8. 


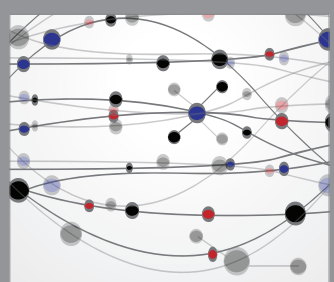

The Scientific World Journal
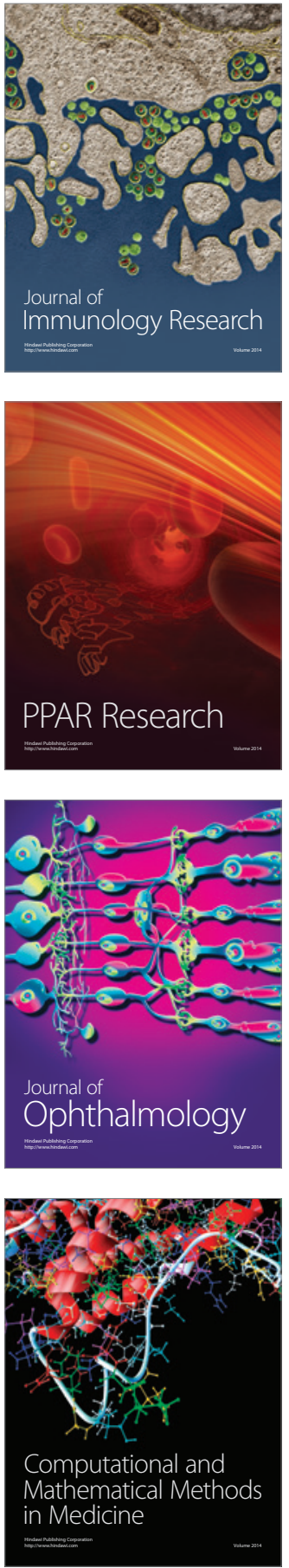

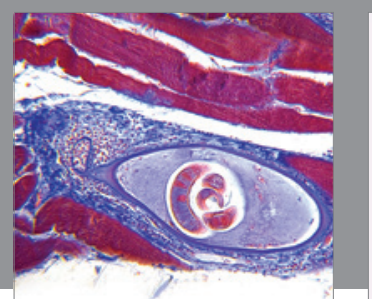

Gastroenterology Research and Practice

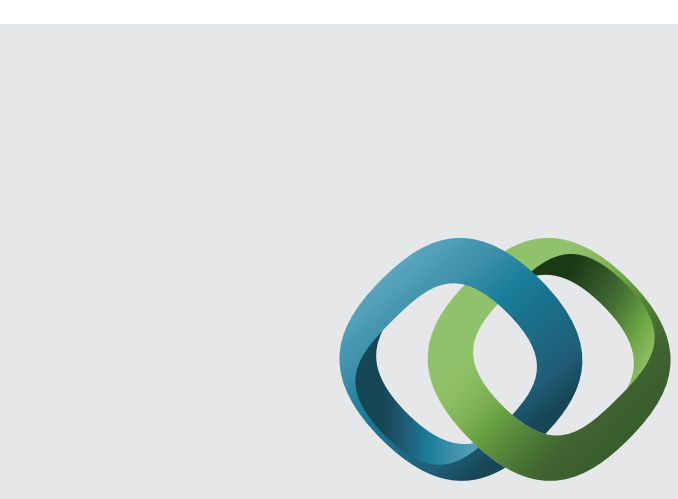

\section{Hindawi}

Submit your manuscripts at

http://www.hindawi.com
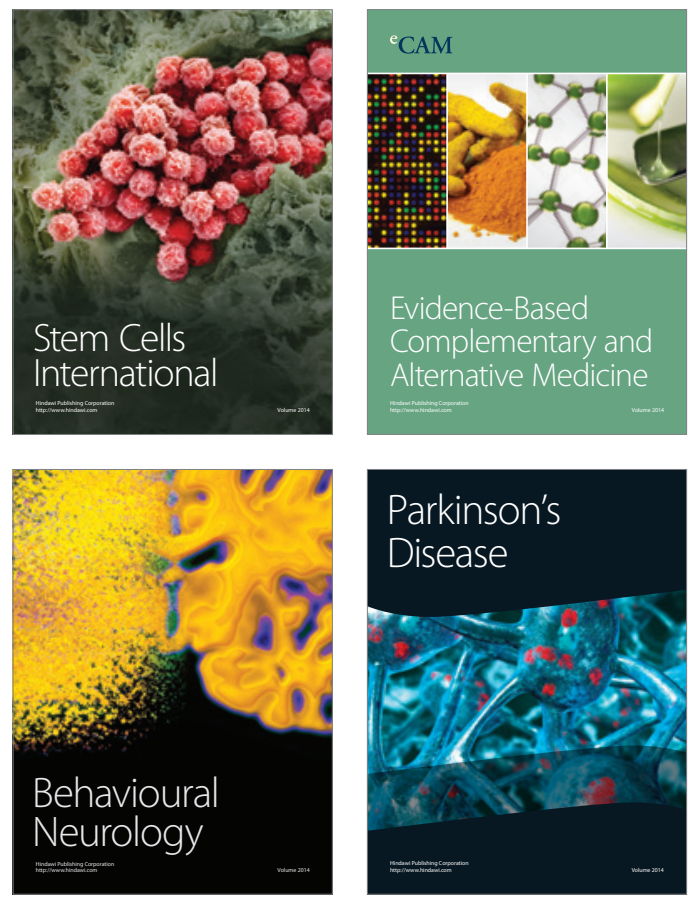
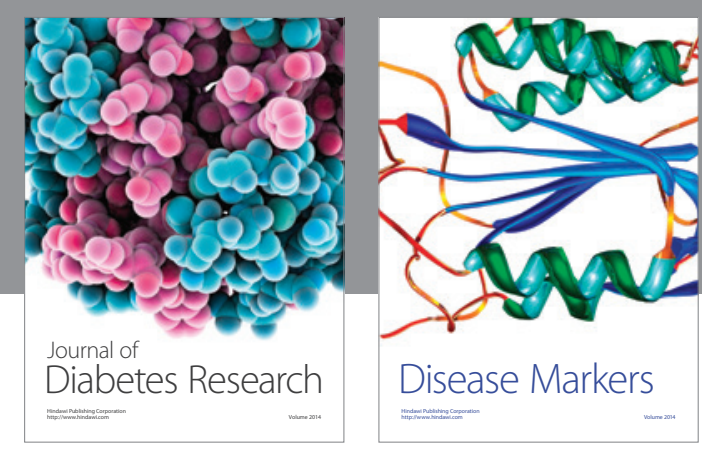

Disease Markers
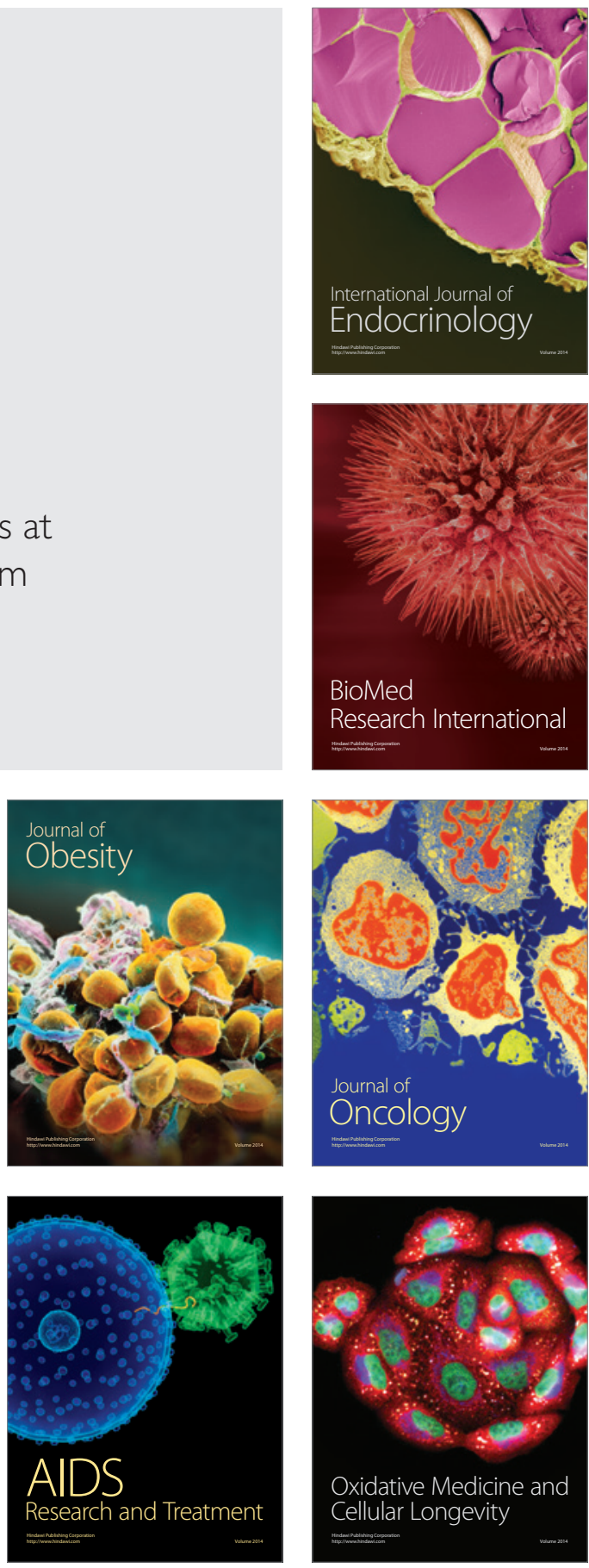